\title{
Comparison of quality properties and identification of acetic acid bacteria for black waxy rice vinegar
}

\author{
Gyeong-Eun Lee ${ }^{1}$, So-Mang Kim ${ }^{1}$, Chang-Ki Huh ${ }^{2}$, In-Kyung Cho ${ }^{3}$, Yong-Doo Kim ${ }^{1 *}$ \\ ${ }^{1}$ Department of Food Science and Technology, Sunchon National University, Sunchon 540-940, Korea \\ ${ }^{2}$ Imsil Institute of Cheese Science, Imsil 566-700, Korea \\ ${ }^{3}$ Department of Food and Nutrition, Nambu University, Gwangju 506-706, Korea
}

\section{흑찰미 식초 제조를 위한 초산균주 동정 및 품질특성 비교

\author{
이경은 ${ }^{1} \cdot$ 김소망 $^{1} \cdot$ 허창기 $^{2} \cdot$ 조인경 ${ }^{3} \cdot$ 김용두 $^{*}$ \\ ${ }^{1}$ 순천대학교 식품공학과, ${ }^{2}$ (재)임실치즈과학연구소, ${ }^{3}$ 남부대학교 식품영양학과
}

\begin{abstract}
This study was carried out to investigate the quality characteristics and identification of acetic acid bacteria for black waxy rice vinegar. Eight (8) strains of acetic acid bacteria were isolated for the production of acetic acid and their acidities were then compared with commercial acetic acid bacteria. Among them, F1, H4, and two types of commercial bacteria (four best strains by vinegar zymogen) were selected. After analyzing the 16S rRNA sequence, both $\mathrm{F} 1$ and $\mathrm{H} 4$ strains were identified as acetobacter genus. Therefore, the F-1 and $\mathrm{H}-4$ strains were named as Acetobacter sp. F-1 and Acetobacter sp. H-4, respectively. Acidity of black waxy rice vinegar during fermentation was steadily increased up to 16 days and the acidity was then constant. Total acidity content was higher when used FV-1 strain. In the results of Hunter's color value of black waxy vinegar, $L$ value was at 75.01 to 80.11, while $(+a)$ value was at 3.34 to 3.92 , and $(+b)$ value was at 12.84 to 18.09 . The major organic acid of the black waxy vinegar was acetic acid. The total organic acid content was high when used H-4, F-1, C-2 and C-1 strains. The total free amino acid content of the black waxy vinegar by strain was the highest $(351.43 \mathrm{mg} \%)$ of F-1 vinegar strain, and the lowest $(247.74 \mathrm{mg} \%)$ of C-2 vinegar strain. A sensory evaluation of black waxy vinegar indicated that F-1 vinegar strain was better than the other samples in aspect of flavor, color, and overall preference.
\end{abstract}

Key words : vinegar, acetic acid, Acetobacter, black waxy rice, fermentation

\section{서 론}

쌀의 기능 성분을 유전 육종적으로 개발하여 특수 기능 성 성분 함량이 높은 품종을 특수미라 부르는데, 유색미 (pigmented rice, Oryza sativa var.)는 이 특수미의 한 종류로 과피에 적갈색이나 자색 등의 색소를 지닌 쌀로서 그 색깔 에 따라 적미, 혹은 흑미로 불리기도 한다(1). 유색미는 1990

*Corresponding author. E-mail : kyd4218@sunchon.ac.kr Phone : 82-61-750-3256, Fax : 82-61-750-3208

Received 5 March 2015; Revised 27 April 2015; Accepted 27 April 2015.

Copyright (c) The Korean Society of Food Preservation. All rights reserved.
년에 처음으로 중국에서 들어와 전남지방을 중심으로 재배 면적이 점차적 확대되어 가고 있지만 우리나라에서는 그 이용이 아직은 일반화되고 있지 않으며, 현재 중국 남부나 동남아시아 지역에서 유색미를 이용한 쌀과자, 간장, 우동, 껌 및 주류 등에 이용되고 있다(2).

유색미는 일반미에 비해 미질이나 식미의 측면에서 떨어 지지만 생육이 왕성하고 다수확성이며, 발아력 및 저장성 뿐만 아니라 cyanidin-3-glucoside 및 malvidin-3-glucoside 등과 같은 안토시아닌 성분을 함유하고 있어 일반미 보다 우수한 것이 특징이다(3). 국립식량과학원(4)에서 유색찰 우량계통과 흑자색 유색미를 교배하여 개발한 보석흑찰은 현미 종피가 진한 흑자색이며 배유는 찰성을 가진 쌀로 특유의 색소 성분 때문에 품질의 다양화와 가공을 위한 
재료가 되는데, 색소 이외에도 단백질, 비타민, 미네랄 등 영양적 가치가 보통의 흰쌀 품종에 비해 월등히 높아 특수 용도미로서 이용가치가 높은 것으로 보고되고 있다(5).

식초는 식품의 맛을 돋워주는 산미료로서 발효과정에서 생성된 독특한 방향과 신맛을 가지고 있는 대표적인 발효식 품으로 곡류, 과실류, 주류 등을 주원료로 하여 초산 발효시 켜 제조하거나 곡물당화액, 과실착즙액 등을 혼합.숙성하 여 만든 양조식초와 빙초산 또는 초산을 음용수로 희석하여 제조하는 합성식초로 구분하고 있다(6,7).

국내에서는 곡물식초의 총산 함유량을 4.0 29.0 w/v\% (초산)로 규정하고 있으며, 사용 균주의 초산 생산 능력 및 발효 방법, 숙성조건 등에 따라 식초 품질에 큰 차이를 나타내는데, 특히 발효 방법보다는 초산 생성균의 기질인 에탄올에 대한 저해작용 및 초산 농도에 대한 내성 정도 등에 따라 균주특성에 절대적으로 영향을 받는 것으로 알려 져 있다(8).

식초는 초산이외의 각종 휘발성 및 비휘발성 유기산류, 당류, 아미노산류, 에스테르류를 함유하고 있어 식욕을 자 극하는 방향과 맛을 가지며 생체 조직 내에서 쉽게 분해되 어 다른 열량원보다 빠르게 칼로리를 발생하는 스테미너 식품으로(9) 예로부터 우리나라 각 가정에서 막걸리로 빚은 곡물식초가 조미료로 사용되어 왔으며, 이중 현미식초는 발효제인 누룩을 첨가하여 알코올 및 초산발효를 거쳐 제조 되는 대표적인 전통식품으로 알려져 있다(10).

현재 국내 식초 산업은 단순 조미료인 빙초산을 희석한 합성식초가 주를 이루다가 1969년 한국농산에서 사과식초 를 출시하면서 양조식초 산업이 급격히 늘어났으며, 1980 년 대부터는 주정을 희석하여 과즙, 무기염을 첨가한 양조 식초의 소비가 증가하였다. 그러나 1990년대 이후부터는 건강지향적인 웰빙식품을 선호하는 소비패턴의 고급화로 식초 시장의 트렌드가 단순 조미용보다는 건강용 식초로 변화되면서 첨가물을 사용하지 않고 $100 \%$ 과실 및 곡물 함유량이 높은 생쌀발효 흑초와 같은 고품질 천연양조식초 가 등장하기 시작하였다(11).

일본의 경우 쌀 식초에 대한 연구가 오래전부터 진행되 어 왔으며, 현재 다양한 품종 및 제법을 활용한 쌀 식초 개발과 함께 이들이 가지는 기능성 및 생리활성 특성들을 규명하는 연구가 지속적으로 이루어지고 있다. 또한 일본 농림규격(Japanese Agricultural Standard, JAS)에 의하면 곡 물식초와 쌀 식초 및 쌀 흑초의 품질기준이 다르게 규격화 되어 있는데(10), 국내의 쌀 식초 경우 대부분 발효 미생물 및 공정개발에 관련된 연구에 치우쳐 있고, 유색미와 같은 새로운 품종을 원료로 한 발효식품 개발 및 발효적성 탐색 등과 관련된 연구는 아직 미진한 실정이다.

이에 본 연구에서는 최근 활용가치가 높은 유색미의 이 용성을 증진하기 위해 천연 흑찰미식초를 개발하고자 진행 하였으며, 초산 발효에 적합한 균주를 선발하여 비교함으
로써 고품질의 흑찰미식초 제조를 위한 기초자료로 활용코 자 하였다.

\section{재료 및 방법}

\section{재 료}

본 실험에 사용한 쌀은 전라남도농업기술원에서 재배하 여 2013년 10월에 수확한 유색미(보석흑찰)를 사용하였고, 양조용수는 정수기(CHP-8800, (주)웅진코웨이, Korea)의 냉수를 $100^{\circ} \mathrm{C}$ 로 가열한 후 $22 \sim 25^{\circ} \mathrm{C}$ 로 냉각하여 사용하였 다. 당화제는 송학곡자에서 구입한 시판 누룩(소율곡누룩, 당화력역가 $300 \mathrm{sp}$ 이상)과 정제효소((주)바이오랜드, 당화 력역가 $100,000 \mathrm{sp}$ )를 사용하였다.

\section{사용균주 및 배지}

실험에 사용한 균주로 초산균은 Acetobacter orleanensis KCTC 12329, Acetobacter pasteurianus KCTC 12289 균주 2종과 순천대학교 식품미생물학 실험실 및 전라남도내 가 정에서 제조한 식초에서 분리한 균주를 사용하였으며, 효 모는 Saccharomyces cerevisiae(Laparisienne, S.I. Lesaffre, France) 건조효모를 사용하였다. 초산균 분리 및 초산생성 우수 균주 선정을 위한 배지는 Difco(USA)사 제품을 구입 하여 사용하였으며 평판배지 (yeast extract $1 \%$, glucose $5 \%$, $\mathrm{CaCO}_{3} 3 \%$, agar $2.5 \%$, ethanol $4 \%, \mathrm{pH} 7.0$ )와 액체배지(yeast extract $1 \%$, glucose $5 \%$, acetic acid $2 \%$, ethanol $7 \%, \mathrm{pH}$ 3.0)는 autoclave에서 $121^{\circ} \mathrm{C}, 15$ 분간 살균하여 $45^{\circ} \mathrm{C}$ 로 냉각 한 다음 에탄올을 무균적으로 첨가하여 사용하였다.

\section{초산생성 균주의 분리}

초산생성 균주는 $A$ orleanensis KCTC 12329, $A$ pasteurianus KCTC 12289 2종을 액체배양 하였으며, 순천 대학교 식품공학과 식품미생물학 실험실 및 전라남도내 가정에서 확보한 종초를 $30^{\circ} \mathrm{C}$ 에서 24 시간 동안 배양하고 활성화시킨 후, 생리식염수로 적절하게 희석하여 $1 \mathrm{~mL}$ 를 분리용 평판배지에 도말 배양하였다. $30^{\circ} \mathrm{C}$ 에서 $3 \sim 4$ 일 동안 배양하여 colony 주위에 투명한 환(還)을 형성하는 균주가 에탄올을 이용하여 초산을 생성할 수 있는 균주로 판정하 고, 보존용 배지에 이식하여 보관하면서 초산 생성 균주로 이용하였다.

\section{초산생성 우수균주 선정 및 동정}

초산 생성능이 우수한 균주를 선정하기 위해 액체배지를 제조하여 분리용 평판배지에서 초산생성 균주로 판정된 균주 및 분양받은 2 종의 균을 각각 접종하고 shaking incubator $(15 \mathrm{rpm})$ 를 $30^{\circ} \mathrm{C}$ 로 조절하여 6 일간 진탕배양한 후 산도를 측정하여 가장 높은 함량을 나타낸 균주를 선발하였 
다. 액체배양된 균을 $3,000 \mathrm{rpm}$ 에서 10 분간 원심분리한 후 Wan 등(12)의 방법에 따라 $518 \mathrm{~F}$ 및 $800 \mathrm{R}$ primer로 colony $\mathrm{PCR}$ 을 수행하여 forward(5') 방향과 reverse(3') 방향을 확 인하기 위해 (주마크로젠(Macrogen Inc. Seoul, Korea)에 16S ribosomal RNA의 염기서열 분석을 의뢰하였으며, 분석된 DNA 염기서열의 일치하는 부분을 NCBI(National Center for Biotechnology Information) BLAST(Basic Local Alignment Search Tool) program에 입력하여 염기서열이 동일한 종을 확인하였다.

\section{초산균 배양}

최종 선발된 초산 균주 4 종을 $121^{\circ} \mathrm{C}$ 에서 15 분간 멸균시 킨 액체배지 $100 \mathrm{~mL}$ 에 접종하고 shaking incubator(150 rpm) 를 이용하여 24시간 동안 진탕배양 시킨 후 배양액을 300 $\mathrm{mL}$ 로 증대하여 $30^{\circ} \mathrm{C}$ 에서 3 일간 진탕배양하였다.

\section{종초 및 알코올 발효액 제조}

보석흑찰미 $4 \mathrm{~kg}$ 를 수세하여 6시간 물에 침지하고, 2시간 물 빼기를 한 후 누룩에 존재하는 전분 분해 효소의 활성화 를 위해 $100^{\circ} \mathrm{C}$ 에서 60 분간 증자하여 고두밥으로 제조한 후 $30^{\circ} \mathrm{C}$ 로 냉각시켰다. 냉각된 고두밥에 물 $7.2 \mathrm{~L}$, 초산 $1 \%$, 건조효모 $0.5 \%$ 및 정제효소 $0.3 \mathrm{w} / \mathrm{w} \%$ 를 첨가한 후 시판누룩을 쌀 양의 $15 \%$ 로 첨가하였으며, $23 \sim 25^{\circ} \mathrm{C}$ 의 온도 를 유지하면서 10 일간 알코올 발효시켰다. 종초는 알코올 함량이 $9.5 \mathrm{w} / \mathrm{v} \%$ 로 발효가 종료된 약주를 여과하여 총산 함량이 $6 \%$ 이상인 식초를 제조하기 위해 알코올 함량을 $7 \%$ 로 제성한 후 배양된 초산균주 $300 \mathrm{~mL}$ 와 같은 양을 혼합하여 $30^{\circ} \mathrm{C}$ 에서 진탕배양 하였다.

\section{식초 제조}

식초는 제성한 알코올 발효액에 균주별로 제조한 종초를 첨가하여 초기산도를 $2 \%$ 로 조절한 후 $30^{\circ} \mathrm{C}$ 에서 16 일 동안 초산발효를 실시하여 식초를 제조하였다. 균주별 식초 제 조과정은 다음 Fig. 1과 같다.

\section{총산 및 색도}

흑찰미식초의 발효기간 중 총산 함량은 시료를 원심분리 하여 상등액 $10 \mathrm{~mL}$ 를 취해 phenolphthalein 지시약을 가하 고 $0.1 \mathrm{~N} \mathrm{NaOH}$ 용액으로 적정한 후 0.006 을 곱하여 acetic acid로 환산하여 나타내었다. 색도 측정은 시료를 원심분리 한 후, 상등액을 여과하여 여과한 여액을 일정량 취해 색도 계(Super color sp-80, Denshoku, Tokyo, Japan)를 이용해 $\mathrm{X}=80.84, \mathrm{Y}=82.22, \mathrm{Z}=92.98$ 인 표준 백색판(standard white plate)으로 보정하여 사용하였다. Hunter's scale값을 3회 반 복 측정하여 그 평균값으로 나타내었으며 대조구는 증류수 $(\mathrm{L}=89.52, \mathrm{a}=0.32, \mathrm{~b}=3.13)$ 를 사용하였다.

\section{유기산 분석}

유기산은 Gancedo와 Luh(13)의 방법에 따라 시료를 전처 리하여 HPLC(Waters M510, Waters Co., Milford, MA, USA) 로 분석하였고, column은 organic acid column(ID 4.6×250 $\mathrm{mm}$, Grace Co., USA)를 사용하였으며, mobile phase는 0.2 $\mathrm{mM}$ potassium dihydrogen phosphate buffer $\mathrm{KH}_{2} \mathrm{PO}_{4}$, flow rate는 $1.0 \mathrm{~mL} / \mathrm{min}$, detector는 diode array detector $(1100$ Series, Agilent Co., USA)를 사용하여 함량은 외부표준법으 로 나타내었다.

\section{유리아미노산}

균주별 식초의 유리아미노산 분석은 유기산 정량과 같은 방법으로 얻은 여액을 Ohara와 Ariyosh(14)의 방법으로 분 석하였다. 즉, 시료 $50 \mathrm{~mL}$ 를 원심분리하여 상징액 $10 \mathrm{~mL}$ 를 취해 sulfosallicylic acid $25 \mathrm{mg}$ 을 가하고 $4^{\circ} \mathrm{C}$ 에서 4 시간 동안 방치 후 원심분리 하였다. 그 상징액을 $0.45 \mu \mathrm{m}$ membrane filter(Millipore Co., USA)로 여과한 여액을 아미노산 자동 분석기(Biochrom 30+, Pharmacia Biotech Ltd., Milton Road, Cambridge, UK)를 이용하여 분석하였다.

\section{관능평가}

균주별 식초의 관능검사는 20 명의 패널을 선정하여 향 (flavor), 색(color), 맛(taste), 전체적인 기호도(overall preference)를 9단계 평가법으로 실시하였다. 채점 기준은 아주 좋다; 9점, 보통이다; 5점, 아주 나쁘다; 1점으로 하였 고, 2 시간 간격으로 시료의 번호를 바꾸어 같은 panel로 3 회 반복하였으며 각 반복 시 가장 높은 점수와 가장 낮은 점수를 제외하고 평균 득점을 구하였다. 관능평가 결과는 Duncan's multiple range test(15)에 의해 평균치간의 유의성 을 검정하였다.

\section{통계처리 방법}

본 실험은 독립적으로 3 회 이상 반복 실시하여 실험결과 를 IBM SPSS statistics(21, IBM Corp., Armonk, NY, USA)를 이용하여 각 실험군간 평균치와 표준편차를 계산하였다.

\section{결과 및 고찰}

\section{초산생성 균주의 분리 및 동정}

초산 생성력이 우수한 균주를 선정하기 위해 화순지역 및 순천대학교 식품미생물학 실험실에서 수집한 종초를 종균 배양하여 초산균 분리용 평판배지에 도말 접종한 후 $30^{\circ} \mathrm{C}$ 에서 배양하면서 colony의 형태적인 특징과 투명환 등 을 관찰한 결과는 Fig. 2 와 같다. 이 중 투명환을 형성하는 8 종의 콜로니를 순수 분리하였으며 $A$ orleanensis KCTC $12329, A$ pasteurianus $\mathrm{KCTC} 12289$ 와 분리 균주를 $7 \%$ 에탄 


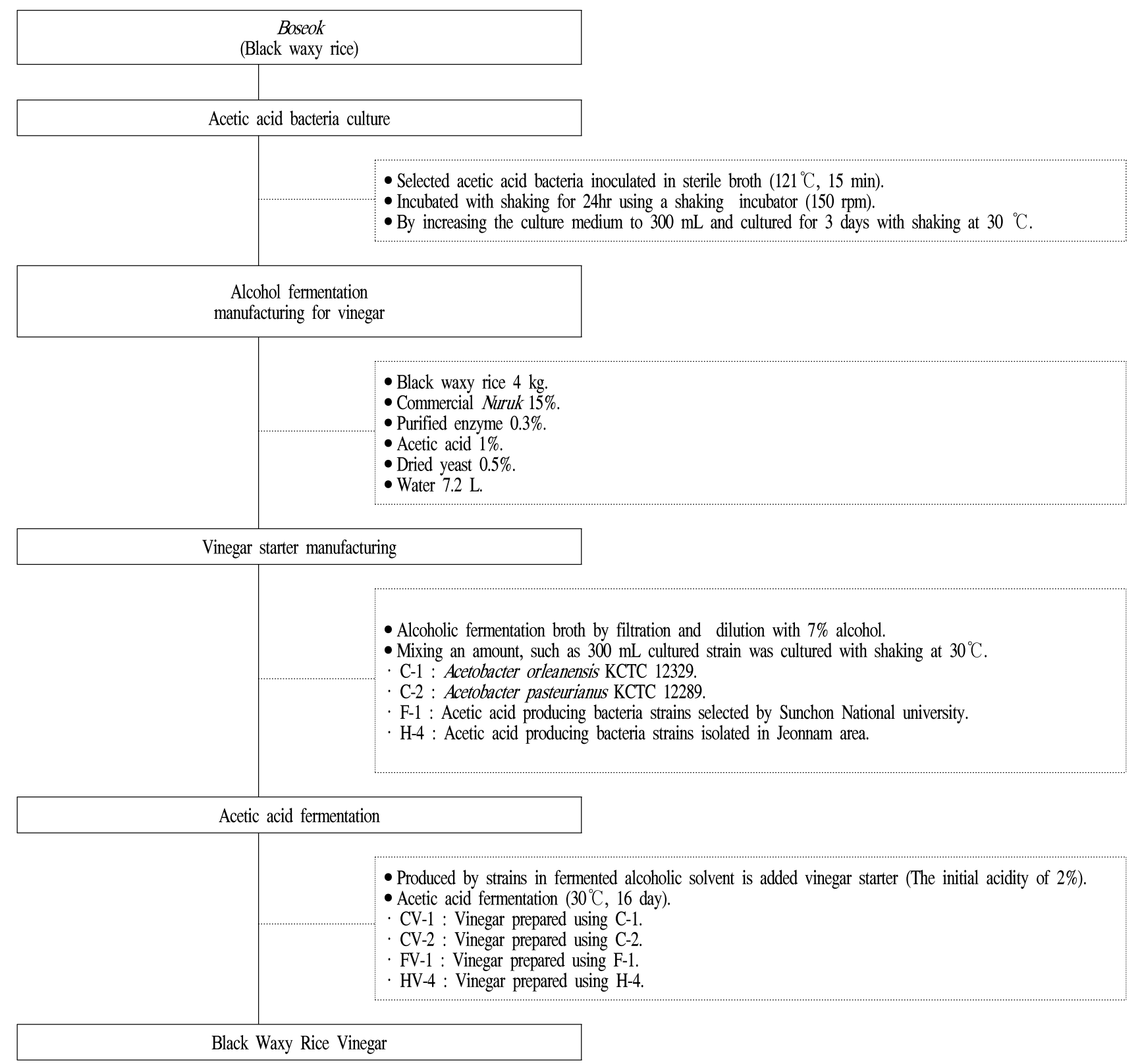

Fig. 1. Schematic diagram for the preparation of black waxy rice vinegar.

올을 함유한 액체배지에 다시 접종하여 $30^{\circ} \mathrm{C}$ 에서 10 일간 진탕배양 한 후 초산 생성능을 비교한 결과는 Table 1 과 같다. 10 개 균주의 초산 생성능은 상대적 활성도로 나타내 었으며, 이 중 $80 \%$ 이상의 높은 생성능이 있는 균주는 시판 균주 2종과 F-1 및 H-4 균주로 각각 $100 \%, 93.76 \%, 85.14 \%$, $80.68 \%$ 로 나타났다. 따라서 초산 생성능이 가장 높게 나타 난 시판균주 2종, F-1 및 H-4 균주 총 4종을 식초 발효 균주 로 선정하였다. 분리균주의 종을 확인하기 위해 $16 \mathrm{~S} \mathrm{rRNA}$ 의 염기서열을 확인한 결과는 Table 2 와 같다. F-1 균주의 경우 forward에 1 번부터 125 번 염기서열과 reverse에 44 부 터 168 번 염기서열이 일치하는 것으로 나타났으며, 이를
BLAST한 결과 $A$ orientalis, $A$ pasteurianus, $A$ tropicalis 등과 같은 초산균의 $16 \mathrm{~S} \mathrm{rRNA}$ 와 일치하는 것으로 나타났 다. H-4균에 대해 정확히 일치하는 염기서열은 forward에 49번부터 232번 염기서열과 reverse에 19부터 202번으로 나타났으며, 일치하는 부분을 BLAST한 결과 $A$ ghanensis, $A$ pasteurianus, $A$ pomorum 등과 같은 초산균의 $16 \mathrm{~S}$ rRNA 와 일치하는 것으로 나타났다. 즉, 분리균주 모두 Acetobacter 속으로 동정되었으나 정확한 specices는 확인 하기 어려움이 있어 F-1 및 H-1 균주를 Acetobacter sp. F-1, Acetobacter sp. H-1으로 명명하였다. 


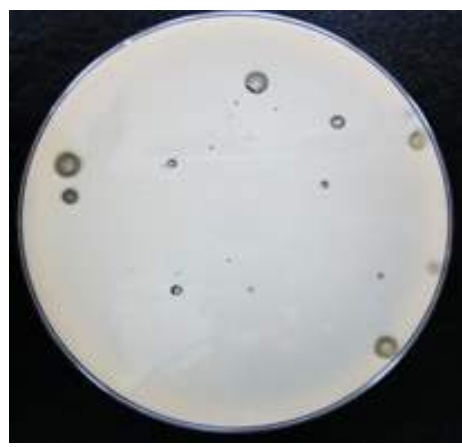

Selected F-1 acetic acid producing bacteria

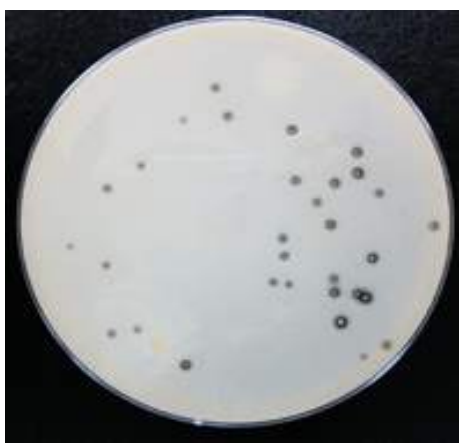

Selected H-4 acetic acid producing bacteria

Fig. 2. Microorganisms selected for manufacturing vinegar.

\section{총 산}

초산균주를 달리하여 제조한 흑찰미식초의 산도 변화는 Fig. 3 과 같다. 초기 산도를 $2 \%$ 로 각각 조정해 담금한 균주 별 흑찰미식초의 발효기간에 따른 산도 변화는 발효 4 일째 부터 CV-1, FV-1, HV-4 및 CV-2 순으로 초산 생성량이 급격하게 증가하였으며 발효 8 일째까지 완만하게 증가하 다가 발효 10 일째에 초산 생성 량이 높아지는 경향을 보였 다. 발효가 진행됨에 따라 꾸준히 높아지다가 일정한 산도 를 유지하였으며 시료구간의 최종 산도는 FV-1 식초의 총 산 함량이 $7.4 \%$ 로 가장 높았다. Keum(16)은 식초 제조 시 발효 15 일까지 산도가 증가한 후 일정한 산도를 유지한다 고 보고하였는데 본 연구결과와 일치하는 경향을 보였다. 균주에 따른 흑찰미식초의 총산 함량의 차이는 균주마다 알코올 발효능이나 초산 생성능이 다르기 때문이라고 생각 된다.

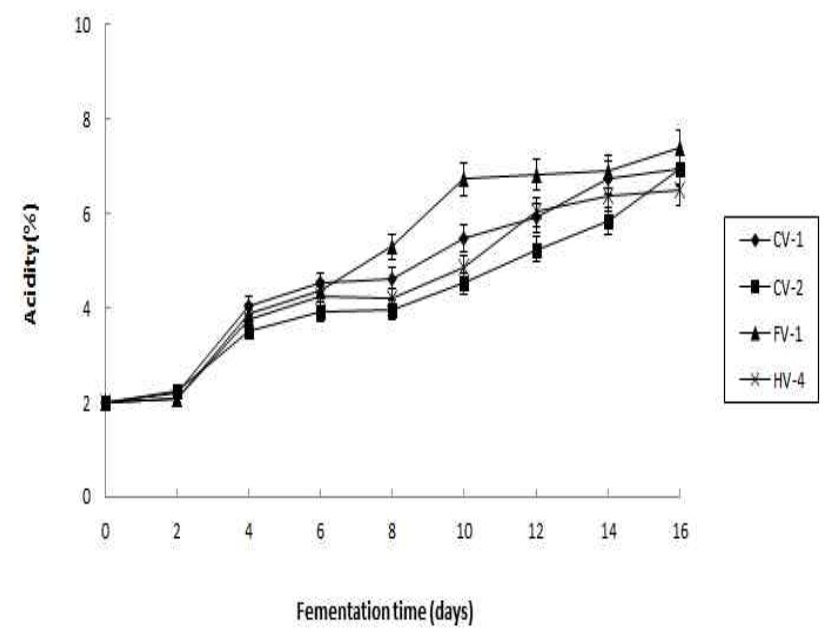

Fig. 3. Changes in the acidity of Boseok black waxy rice vinegar during fermentation at $30^{\circ} \mathrm{C}$.

CV-1, vinegar prepared using Acetobacter orleanensis KCTC 12329; CV-2, vinegar prepared using Acetobacter pasteurianus KCTC 12289; FV-1, vinegar prepared using acetic acid producing bacteria strains selected by Sunchon National university; HV-4, vinegar prepared using acetic acid producing bacteria strains isolated in Jeonnam area.
Table 1 . The test strain's ability to produce acetic acid after isolation from conventional vinegar

\begin{tabular}{ccc}
\hline Strains No. & Acidity $(\%)$ & Relative activity (\%) \\
\hline C-1 ${ }^{1)}$ & $7.36 \pm 0.02$ & 93.76 \\
C-2 $2^{2)}$ & $7.85 \pm 0.03$ & 100 \\
F-1 & $6.68 \pm 0.02$ & 85.14 \\
F-2 & $3.60 \pm 0.01$ & 45.90 \\
H-1 & $6.10 \pm 0.01$ & 77.63 \\
H-2 & $5.42 \pm 0.01$ & 69.06 \\
H-3 & $4.38 \pm 0.02$ & 55.77 \\
H- 4 & $6.33 \pm 0.02$ & 80.68 \\
H- 5 & $5.98 \pm 0.02$ & 76.22 \\
H-6 & $6.15 \pm 0.04$ & 78.30
\end{tabular}

${ }^{1)} \mathrm{C}-1$, Acetobacter orleanensis KCTC 12329

${ }^{2)} \mathrm{C}-2$, Acetobacter pasteurianus KCTC 12289

${ }^{3)} \mathrm{F}$, acetic acid producing bacteria strains selected by the department of food science and technology at Sunchon National university.

${ }^{4} \mathrm{H}$, acetic acid producing bacteria strains isolated from house holds in Jeonnam area

색 도

균주별 흑찰미식초의 색도 측정 결과는 Table 3에서 보는 바와 같다. 명도를 나타내는 L값은 75.01 80.11로 CV-1에 서 가장 높은 수치를 보였고 FV-1이 가장 낮은 수치를 보였 다. 적색도를 나타내는 a값은 3.34 3.92로 $\mathrm{CV}-1$ 에서 가장 높았으며, 황색도를 나타내는 b값은 12.84 18.09로 FV-1 에서 가장 높았고 CV-1에서 가장 낮게 나타났으나 시료구 의 $\mathrm{L}, \mathrm{a}$ 및 $\mathrm{b}$ 값 모두 다소 큰 차이는 보이지 않았다. Mo 등(17)은 오미자 추출액 농도에 따른 초산발효 전과 후의 색도를 비교한 결과 $\mathrm{L}$ 및 $\mathrm{b}$ 값은 발효 전후로 유의성이 없었 으나 초산발효가 진행됨에 따라 $\mathrm{a}$ 값의 유의적 차이가 나타 남을 보고한바 있다. $\mathrm{Kim}$ 등(18)은 시판 과실식초 중 주정을 발효시켜 제조한 식초와 알코올 발효를 거쳐 제조된 식초의 색도를 측정한 결과 알코올 발효와 초산발효가 모두 진행될 수록 식초의 색이 더 진해지는 것을 확인한 바 있으며, Kim 
Table 2. 16S rRNA partial sequencing of isolated acetic acid-producing bacteria

\begin{tabular}{|c|c|c|}
\hline Sample & Primer & Nucleotide sequence \\
\hline \multirow[b]{2}{*}{ F-1 } & $518 \mathrm{~F}$ & $\begin{array}{l}\text { GGGGGGGAATCGNTGCTCGGTATGACGGGGCGTAAAGGGCGTGAAGGCGGTTTGTACAGTCAGAATGTGA } \\
\text { AATCCCCGGGGCTTAACCTGGGGAGCTGCATTTGATACGTGCAGACTAGAGTGTGAGAGAGGGTTGTGGA } \\
\text { ATTCCCAGTGTAGAGGTGAAATTCGTAGATATTGGGAAGAACACCGGTGGCGAAGGCGGC }\end{array}$ \\
\hline & $800 \mathrm{R}$ & $\begin{array}{l}\text { GAGGGCTTTATTTCGCGCATCAGCGTCAGTAATGAGCCAGGTTGCCGCCTTCGCCACCGGTGTTCTTCCCA } \\
\text { ATATCTACGAATTTCACCTCTACACTGGGAATTCCACAACCCTCTCTCACACTCTAGTCTGCACGTATCAAA } \\
\text { TGCAGCTCCCAGGTTAAGCCGGGGATTTCACATCTGACTGTACAAACCGCCTACACGCCCTTTACGCCCA } \\
\text { GTCATTCCGAGCAACGCTAGCCCCCTTCGTATTACCGCGGCTGCTGGA }\end{array}$ \\
\hline \multirow{2}{*}{$\mathrm{H}-4$} & $518 \mathrm{~F}$ & $\begin{array}{l}\text { GGGGGAGCTCGTTGCCNGATGACTGGGCGTAAGGGCGTGTAGGCGGTTTGTACAGTCAGATGTGAAATCC } \\
\text { CCGGGCTTAACCTGGGAGCTGCATTTGATACGTGCAGACTAGAGTGTGAGAGAGGGTTGTGGAATTCCCA } \\
\text { GTGTAGAGGTGAAATTCGTAGATATTGGGAAGAACACCGGTGGCGAAGGCGGCAACCTGGCTCATTACTG } \\
\text { ACGCTGAGGCGCGAAAGCGTGGGAGCAAACAGGATTAGATACCCTGGTAAN }\end{array}$ \\
\hline & $800 \mathrm{R}$ & $\begin{array}{l}\text { GGGCGTCATTCGCGCCTCGCGTCAGTAATGAGCCAGGTTGCCGCCTTCGCCACCGGTGTTCTTCCCAATAT } \\
\text { CTACGAATTTCACCTCTACACTGGGAATTCCACAACCCTCTCTCACACTCTAGTCTGCACGTATCAAATGCA } \\
\text { GCTCCCAGGTTAAGCCCGGGGATTTCACATCTGACTGTACAAACCGCCTACACGCCCTTACGCCCAGTCA } \\
\text { TTCCGAGCAACGCTAGCCCCCTTCGTATTACCGCGNGCTGCTGGAAN }\end{array}$ \\
\hline
\end{tabular}

Table 3. The Hunter's color value of Boseok black waxy rice vinegar that was prepared using acetic acid bacteria strains

\begin{tabular}{cccc}
\hline Sample $^{1)}$ & \multicolumn{3}{c}{ Hunter's color value } \\
\cline { 2 - 4 } & $\mathrm{L}$ & $\mathrm{a}$ & $\mathrm{b}$ \\
\hline $\mathrm{CV}-1$ & $80.11 \pm 0.04^{2)}$ & $3.92 \pm 0.03$ & $12.84 \pm 0.01$ \\
$\mathrm{CV}-2$ & $79.12 \pm 0.02$ & $3.34 \pm 0.05$ & $14.73 \pm 0.46$ \\
FV-1 & $75.01 \pm 0.04$ & $3.50 \pm 0.07$ & $18.09 \pm 0.01$ \\
HV-4 & $77.75 \pm 0.06$ & $3.51 \pm 0.03$ & $15.16 \pm 0.03$ \\
\hline
\end{tabular}

${ }^{1)} \mathrm{CV}$-1, vinegar prepared using Acetobacter orleanensis KCTC 12329; CV-2, vinegar prepared using Acetobacter pasteurianus KCTC 12289; FV-1, vinegar prepared using acetic acid producing bacteria strains selected by Sunchon National university; HV-4, vinegar prepared using acetic acid producing bacteria strains isolated in Jeonnam area.

${ }^{2)}$ All values are mean $\pm \mathrm{SD}$

등(7)도 마찬가지로 시판 현미식초의 주정 첨가 유무에 따 라 색상에 영향을 주는 것으로 보고한 바 있다. 또한 흑자색 계열인 유색미 분말의 색도 측정결과(19)와 본 연구에서 제조한 흑찰미식초의 색도를 비교하였을 때 $\mathrm{L}$ 및 $\mathrm{b}$ 값이 원료인 흑자색 유색미보다 높게 나타났고, a값은 비슷한 함량을 보였는데, 이는 곡물 식초 제조시 첨가되는 덧술의 보존기간이 길어지면 amino carbonyl 반응에 의한 갈변으로 색이 진하게 나타난다는 연구결과에 의한 것으로 보이며 (20), 이와 같이 식초의 색상은 발효방법 뿐만 아니라 원료 에 따라서도 어느 정도 영향을 미치는 것으로 사료된다.

\section{유기산}

유기산은 식초의 산미와 지미에 영향을 주어 식초 품질 에 중요한 영향을 미친다(21). 균주별 흑찰미식초를 $30^{\circ} \mathrm{C}$ 에 서 16 일동안 발효시켜 유기산을 분석한 결과는 Table 4 와 같다. 균주별 흑찰미식초에서 oxalic acid, tartaric acid, malic acid, lactic acid, acetic acid, citric acid 6종이 검출되었으며 총 유기산 함량은 전반적으로 큰 차이는 없으나 분리균주 $\mathrm{H}-4$ 식초의 acetic acid 함량이 $6.3 \%$ 로 가장 높았고 균주
C-1 식초가 5.8\%로 가장 낮은 함량을 보였다. 식초의 주요 유기산은 acetic acid임을 확인하였으며 acetic acid를 제외 한 다른 유기산 성분 함량은 유사한 경향을 나타냈다. 이는 균주가 유기산 성분 및 함량의 변화에 영향을 미치지 않음 을 보였다. 총 유기산 함량에 대한 acetic acid 비율(A/T)은 $0.97 \sim 0.99$ 로 나타났으며 $\operatorname{Kim}(7)$ 등의 시판 현미식초의 유 기산 분석결과와 유사한 경향을 보였다. 곡물식초에서 나 타나는 lactic acid는 곡류식초 제조시 발효초기 단계에서 젖산균이 생육하여 lactic acid를 생성하는 것으로 추정되며 (22), 특히 곡류식초에서 lactic acid의 함량이 높으면 군냄새 의 원인이 되기도 한다고 알려지고 있다(6). 이 외에 oxalic acid, tartaric acid, malic acid, citric acid은 흑찰미 원료에 존재하던 성분에서 나왔다고 생각된다.

Table 4. The organic acid content in Boseok black waxy rice vinegar that was prepared using acetic acid bacteria strains

\begin{tabular}{lcccc}
\hline \multicolumn{1}{c}{ Organic acids } & CV-1 & CV-2 & FV- 1 & HV-4 \\
\hline Oxalic acid & $0.03 \pm 0.12^{2)}$ & $0.03 \pm 0.01$ & $0.04 \pm 0.02$ & $0.04 \pm 0.04$ \\
Tartaric acid & $0.02 \pm 0.02$ & $0.02 \pm 0.09$ & $0.02 \pm 0.01$ & $0.03 \pm 0.02$ \\
Malic acid & $0.04 \pm 0.02$ & $0.04 \pm 0.05$ & $0.04 \pm 0.03$ & $0.07 \pm 0.01$ \\
Lactic acid & $0.03 \pm 0.04$ & $0.03 \pm 0.03$ & $0.03 \pm 0.04$ & $0.04 \pm 0.16$ \\
Acetic acid & $5.80 \pm 0.25$ & $5.83 \pm 0.16$ & $6.23 \pm 0.11$ & $6.34 \pm 0.23$ \\
Citric acid & $0.04 \pm 0.02$ & $0.04 \pm 0.02$ & $0.02 \pm 0.05$ & $0.03 \pm 0.02$ \\
Total organic acids & 5.96 & 5.99 & 6.38 & 6.55 \\
A/T & 0.97 & 0.99 & 0.98 & 0.97 \\
\hline
\end{tabular}

${ }^{1)} \mathrm{CV}-1$, vinegar prepared using Acetobacter orleanensis KCTC 12329; CV-2, vinegar prepared using Acetobacter pasteurianus KCTC 12289; FV-1, vinegar prepared using acetic acid producing bacteria strains selected by Sunchon National university; HV-4, vinegar prepared using acetic acid producing bacteria strains isolated in Jeonnam area.

${ }^{2)}$ All values are mean $\pm \mathrm{SD}$.

${ }^{3}$ Ratio of acetic acid to total organic acids. 


\section{유리 아미노산}

균주별 흑찰미식초의 유리아미노산 함량을 분석한 결과 는 Table 5에서 보는 바와 같다. 총 유리아미노산 함량은 $351.43 \mathrm{mg} \%$ 로 균주 F-1 식초가 가장 높았으며, $247.74 \mathrm{mg} \%$ 으로 균주 C-2 식초가 가장 낮은 함량을 보였다. 모든 시료 구에서 histidine, arginine, lysine은 검출되지 않았으며 Lee 등(23)이 보고한 원료 흑찰미의 아미노산 함량보다 현저히 낮은 함량을 보였다. 이는 식초의 아미노산은 초산발효 중 초산균이 아미노산을 자화하여 $38 \sim 60 \%$ 가 감소된다고 하 였으며 특히 glutamic acid, aspartic acid, proline의 감소가 크다고 보고된 바 있다(24). 현미식초의 유리아미노산 함량 을 분석한 연구들 $(25,26)$ 에 비해 본 연구의 흑찰미식초의 유리아미노산 함량이 현저히 높은 경향을 나타내었는데, 이는 쌀의 품종 및 발효조건, 발효방식, 원료함량 등이 영향 을 미친 것으로 보인다. 또한 본 연구에서 시료구마다 유리 아미노산 함량의 차이를 보였으며, 이는 초산균의 종류에

Table 5. The free amino acid content in Boseok black waxy rice vinegar that was prepared using acetic acid bacteria strains

\begin{tabular}{|c|c|c|c|c|}
\hline Components & $\left(\mathrm{CV}-1^{1)}\right.$ & $\mathrm{CV}-2$ & FV-1 & $\frac{\text { (mg }}{\text { HV-4 }}$ \\
\hline Aspartic acid & 8.72 & 4.45 & 5.12 & 8.69 \\
\hline Serine & 5.95 & 23.43 & 38.65 & 47.76 \\
\hline Glutamic acid & 18.58 & 4.24 & 15.45 & 10.97 \\
\hline Glycine & 8.09 & 15.64 & 7.44 & 15.26 \\
\hline Histidine & .) & - & - & - \\
\hline Arginine & - & - & - & - \\
\hline Threonine & 6.93 & 3.08 & 9.05 & 3.19 \\
\hline Alanine & 91.08 & - & - & - \\
\hline Proline & 50.02 & - & 65.46 & 32.65 \\
\hline Tyrosine & 21.57 & 59.89 & 31.03 & 47.52 \\
\hline Cystine & 2.31 & 8.27 & 6.14 & 9.55 \\
\hline Valine & 15.46 & 12.43 & 21.20 & 12.87 \\
\hline Methionine & 10.82 & 32.90 & 15.11 & 25.11 \\
\hline Lysine & - & - & - & - \\
\hline Isoleucine & 4.12 & 9.46 & 3.76 & 9.86 \\
\hline Leucine & 28.62 & 67.05 & 84.12 & 65.84 \\
\hline Tryptophane & 2.02 & 6.90 & 13.39 & 7.99 \\
\hline Phenylalanine & 10.95 & - & 35.51 & 19.60 \\
\hline $\mathrm{TAA}^{3)}$ & 283.24 & 247.74 & 351.43 & 316.86 \\
\hline $\mathrm{EAA}^{4)}$ & 78.92 & 131.82 & 182.14 & 144.46 \\
\hline
\end{tabular}

${ }^{1)} \mathrm{CV}-1$, vinegar prepared using Acetobacter orleanensis KCTC 12329; CV-2, vinegar prepared using Acetobacter pasteurianus KCTC 12289; FV-1, vinegar prepared using acetic acid producing bacteria strains selected by Sunchon National university; HV-4, vinegar prepared using acetic acid producing bacteria strains isolated in Jeonnam area.

${ }^{2)}$ Not detected.

${ }^{3)}$ Total free amino acid.

${ }^{4)}$ Essential amino acid (Thr+Val+Met+Ile+Leu+Phe+Lys+Typ).
따라 아미노산을 자화하는 능력이 각기 다르기 때문에 나타 난 결과라 사료된다.

\section{관능평가}

균주에 따른 흑찰미식초의 관능평가 결과는 Table 6과 같다. 향의 경우 균주 F-1을 이용한 식초의 기호도가 6.0 으 로 가장 좋았으며, 분리균주 $\mathrm{H}-4$ 를 이용한 식초가 4.7 로 가장 낮은 기호도를 보였다. 색은 $\mathrm{C}-1, \mathrm{C}-2$ 및 F-1 균주가 각각 $5.3,5.8,6.5$ 순으로 나타났으며 $\mathrm{H}-1$ 균주로 제조한 식초는 4.5 로 가장 낮은 기호도를 보였다. 맛의 경우 C-1균 주로 제조한 식초가 6.0으로 가장 높게 나타났고, H-4 균주 로 제조한 식초가 4.2로 가장 낮게 나타났으나 시료구별 유의적인 차이를 보이지 않았다. 전체적인 기호도는 F-1 균주로 제조한 식초가 6.4로 가장 높은 기호도를 보였고, 다음으로 균주 C-2 균주로 제조한 식초의 기호도가 6.2로 높게 나타났다. H-4로 제조한 균주는 향, 색, 맛 및 전체적인 기호도 면에서 가장 낮게 나타나 흑찰미식초 제조에 적합하 지 않는 것으로 판단되며, 이와 같은 결과를 토대로 맛을 제외한 향, 색, 및 전체적인 기호도에서 가장 우수한 기호도 를 보인 F-1 균주가 흑찰미식초 제조에 적합할 것으로 생각 된다.

Table 6. Sensory evaluation of Boseok black waxy rice vinegar that was prepared using acetic acid bacteria strains

\begin{tabular}{ccccc}
\hline \multirow{2}{*}{ Sample $^{1)}$} & \multicolumn{4}{c}{ Sensory evaluation } \\
\cline { 2 - 5 } & Color & Taste & Flavor & $\begin{array}{c}\text { Overall } \\
\text { preference }\end{array}$ \\
\hline CV-1 & $5.5 \pm 0.70^{23) 3 \mathrm{ab}}$ & $5.3 \pm 0.82^{\mathrm{ab}}$ & $5.4 \pm 2.50^{\mathrm{a}}$ & $5.7 \pm 0.94^{\mathrm{b}}$ \\
CV-2 & $5.4 \pm 0.69^{\mathrm{ab}}$ & $5.8 \pm 0.78^{\mathrm{bc}}$ & $6.0 \pm 1.88^{\mathrm{a}}$ & $6.2 \pm 0.78^{\mathrm{bc}}$ \\
FV-1 & $6.0 \pm 0.81^{\mathrm{b}}$ & $6.5 \pm 1.26^{\mathrm{c}}$ & $5.2 \pm 1.75^{\mathrm{a}}$ & $6.4 \pm 1.17^{\mathrm{c}}$ \\
HV-4 & $4.7 \pm 0.82^{\mathrm{a}}$ & $4.5 \pm 1.43^{\mathrm{a}}$ & $4.2 \pm 1.54^{\mathrm{a}}$ & $4.9 \pm 0.73^{\mathrm{a}}$ \\
\hline
\end{tabular}

${ }^{1)} \mathrm{CV}$-1, vinegar prepared using Acetobacter orleanensis KCTC 12329; CV-2, vinegar prepared using Acetobacter pasteurianus KCTC 12289; FV-1, vinegar prepared using acetic acid producing bacteria strains selected by Sunchon National university; HV-4, vinegar prepared using acetic acid producing bacteria strains isolated in Jeonnam area.

${ }^{2)}$ All values are mean $\pm \mathrm{SD}$.

${ }^{3)}$ Mean \pm SD with different superscripts within the same column are significantly different $(\mathrm{p}<0.05)$ by Duncan's multiple range test.

\section{요 약}

흑찰미를 이용한 식초를 개발하기 위해 초산생성능이 우수한 초산균을 분리 및 동정하여 균주별로 제조한 식초의 품질특성을 확인한 결과는 다음과 같다. 초산 생성력이 우 수한 균주를 선정하기 위해 초산균 분리용 평판배지에 도말 하여 8종의 균주를 순수 분리하였으며, 이들 균주와 시판 균주 2종의 초산 생성능을 확인한 결과 가장 높게 나타난 시판균주 2종, 분리균주 F-1 및 H-4를 식초 발효 균주로 
선정하였다. 분리균주의 종을 확인하기 위해 $16 \mathrm{~S} \mathrm{rRNA}$ 의 염기서열을 분석한 결과 분리균주 모두 Acetobacter 속으로 동정되었으며, F-1 및 H-1 균주를 Acetobacter sp. F-1, Acetobacter sp. H-1으로 명명하였다. 초산균 균주를 달리하 여 제조한 흑찰미식초의 산도 변화는 발효가 진행됨에 따라 발효 16 일까지 꾸준히 높아지다가 일정한 산도를 유지하였 으며 시료구간의 최종 산도는 FV-1 식초의 총산 함량이 $7.4 \%$ 로 가장 높았다. 색도의 경우 L값 $75.01 ~ 80.11$, a값 $3.34 \sim 3.92$, b값 12.84 18.09 범위로 나타났다. 균주별 흑찰 미식초의 주요 유기산은 acetic acid으로 나타났으며 총 유 기산 함량은 HV-4, FV-1, CV-2 및 CV-1 식초 순으로 나타 났다. 총 유리아미노산 함량은 분리균주 F-1 식초가 351.43 $\mathrm{mg} \%$ 으로 함량이 가장 높았으며, 균주 C-2 식초가 247.74 $\mathrm{mg} \%$ 으로 가장 낮은 함량을 보였다. 균주에 따른 흑찰미식 초의 관능평가 결과는 분리균주 $\mathrm{H}-4$ 로 제조한 식초는 전반 적으로 낮은 기호도를 보였으며, 분리균주 F-1로 제조한 식초가 향, 색 및 종합기호도에서 가장 높은 기호도를 나타 내었다. 이와 같은 결과를 토대로 가장 우수한 기호도를 나타낸 F-1 균주가 흑찰미식초 제조에 적합할 것으로 생각 된다.

\section{감사의 글}

본 연구는 농촌진흥청 및 전라남도농업기술원의 연구비 지원으로 수행된 연구 결과의 일부로 이에 감사드립니다.

\section{References}

1. Kim JD, Kim K, Eun JB (1999) Storage of black rice using flexible packaging materials. Korean J Food Sci Technol, 31, 158-163

2. Kim JS (1997) Using specialty rice cooked foods development. Rural Living Sci, 18, 5-8

3. Han SJ, Ryu SN, Park SZ, Kim HY (2004) Analysis of cyanidin 3-glucoside in blackish purple rice. J Crop Sci Biotech, 49, 97-101

4. Lee JH, Lee SB, Kim HY, Yang CI, Kim MK, Jeon YH, Lee KS, Kim YG, Jeong OY, Hwang HG, Choi YH, Yang SJ, Cho YC, Oh SK, Yea JD, Lee JH, Won YJ, Lee JI (2011) A new black pericarp, medium-ripening glutinous rice cultivar "Boseogheugchal". Korean J Breed Sci, 43, 600-605

5. Gu D, Meiyu X (1992) A study on special nutrient of purple black glutinous rice. Scientia Agric Sinica, 25, 36-41
6. Jeong YJ, Lee MH (2000) A view and prospect of vinegar industry. Food Ind Nutr, 5, 7-12

7. Kim GR, Yoon SR, Lee JH, Yeo SH, Kim TY, Jeong YJ, Yoon KY, Kwon JH (2009) Quality comparison of commercial brown rice vinegar fermented with and without ethanol. Korean J Food Preserv, 16, 893-899

8. Yoon HN (1998) Simultaneous gas chromatographic analysis of ethanol and acetic acid in vinegar. Korean J Food Sci Technol, 30, 1247-1251

9. Hwan SH, Hong JH, Jeong YJ, Youn KS (2002) Effects of the proportions of wall materials on the characteristics of spray dried vinegar. Korean J Food Preserv, 9, 189-193

10. Baek CH, Jeong DH, Baek SY, Choi JH, Park HY, Choi HS, Jeong ST, Kim JH, Jeong YJ, Kwon JH, Yeo SH (2013) Quality characteristics of farm-made brown rice vinegar via traditional static fermentation. Korean J Food Preserv, 20, 564-572

11. Jeong YJ (2009) Current trends and future prospects in the Korean vinegar industry. Food Sci Ind, 42, 52-59

12. Wan M, Rosenberg JN, Faruq J, Betenbaugh MJ, Xia J (2011) An improved colony PCR procedure for genetic screening of chlorella and related microalgae. Biotechnol Lett, 33, 1615-1619.

13. Gancedo MC, Luh BS (1986) HPLC analysis of organic acids and sugar in tomato juice. J Food Sci, 51, 571-580

14. Ohara I, Ariyoshi S (1979) Comparison of protein precipitants for the determination of free amino acid in plasma. Agric Biol Chem, 43, 1473

15. Duncan DB (1995) Multiple range and multiple F test. Biometrics, 11

16. Keum JH (1999) Studies on garlic and pumpkin vinegar. Korean J Food Nutr, 12, 518-522

17. Mo HW, Jung YH, Jeong JS, Choi KH, Choi SW, Park CS, Choi MA, Kim ML, Kim MS (2013) Quality characteristics of vinegar fermented using Omija (Schizandra Chinensis Baillon). J Korean Soc Food Sci Nutr, 42, 441-449

18. Kim KO, Kim SM, Kim SM, Kim DY, Jo DJ, Yeo SH, Jeong YJ, Kwon JH (2013) Physicochemical properties of commercial fruit vinegars with different fermentation methods. J Korean Soc Food Sci Nutr, 42, 736-742

19. Ha TY, Park SH, Lee CH, Lee SH (1999) Chemical composition of pigmented rice varieties. Korean J Food Sci Technol, 31, 336-341

20. Sim GS (1984) Metabolism and health of vinegar. Food Sci Ind, 17, 51-59

21. Furukawa S, Udea R (1963) Studies on non-volatile 
organic acid in vinegar, contents of non-volatile organic acid in commercial vinegars. J Ferment Technol, 41, 14-19

22. Lee YC, Jang OY, Kim HW, Choi CU, Yoon SK (1999) Physicochemical characteristics of traditional vinegars in andong province. Korean J Dietary culture, 14, 17-20

23. Lee MK, Kim YM, Park JS, Na HS (2012) Nutritional characteristics of pigmented rice. Korean J Food Preserv, 19, 235-242

24. Yulkimichi K, Yasuhiro U, Fujihara Y (1987) The general composition inorganic cations free amino acids and organic acid of special vinegars. Nippon Shokuhin Kogyo Gakkaishi, 34, 592-598

25. Joo KH, Cho MH, Park KJ, Jeong SW (2009) Effects of fermentation method and brown rice content on quality characteristics of brown rice vinegar. Korean J Food Preserv, 16, 33-39

26. Baek $\mathrm{CH}$, Jeong DH, Baek SY, Choi JH, Park HY, Choi HS, Jeong ST, Kim JH, Jeong YJ, Kwon JH, Yeo SH (2013) Quality characteristics of farm-made brown rice vinegar via traditional static fermentation. Korean J Food Preserv, 20, 564-572 